\title{
The mycosociology of macrofungi as indicators of the presence of stipitate hydnoids
}

\author{
Feest $\mathrm{A}^{1 \& 2}$ and Smith $\mathrm{JH}^{3}$ \\ ${ }^{l}$ Institute of Advanced Studies, University of Bristol, University Walk, Bristol BS ITR \\ ${ }^{2}$ Ecosulis, The Rickyard, Newton St Loe, Bath BA2 9BT \\ ${ }^{3}$ 13, Baden Road, Redfield, Bristol BS5 9QE
}

Feest A, Smith JH 2015 - The mycosociology of macrofungi as indicators of the presence of stipitate hydnoids. Mycosphere 6(1), 127-132, Doi 10.5943/mycosphere/6/2/1

\begin{abstract}
Using a biodiversity quality approach to measuring the biodiversity of macrofungi (entailing the use of a standardised survey methodology and the creation of a set of Biodiversity quality indices) has allowed sites to be compared and the relationship between species shown. The example of stipitate hydnoids may be a guide to future studies on other species groups.
\end{abstract}

Key Words - Biodiversity quality - mycorrhizal fungi - standardized sampling - Twinspan.

\section{Introduction}

The activities of fungi are essential for the functioning of ecosystems and the biodiversity of macrofungi is often a reflection of the overall biodiversity (Christensen et al 2004). Macrofungi are a component that in some ecosystems are essential keystone organisms (Baldwin et al 2002, Dix \& Webster 1995, Smith \& Read 1997) and in particular the role of mycorrhizal species in plant nutrition is so fundamental that it is sometimes suggested that the colonisation of land was only possible through the creation of mycorrhizae and pioneer plants such as Rhynia appear to have beeen mycorrhizal (Remy et al 1997). Within the mycorrhizal species the ectomycorrhizal species are very evident when forming fruit bodies and much study has been devoted to these species.

Whilst macrofungi have been subjected to considerable study these studies are often limited to the occurrence of the fruit bodies (Ratowsky 2007). Studies looking at the occurrence of mycorrhizal species on roots have expanded (Walker et al. 2008) but there are problems in the interpretation of root tips in that a) presence on a root tip does not necessarily relate to the occurrence and abundance of fruit bodies b) it seems to be assumed that the root tip association is stable and unvarying so that much is assumed from single sampling whilst the evidence is that root tip occurrence is dynamic, unstable and subject to considerable variance (seasonally or annually) (Walker et al. 2008) and c) the identity of species is somewhat hazy and often limited to genus and a number to indicate difference from other members of the genus e.g. Russula 6 or Leccinum 2 (Feest 2009).

Macrofungal surveys are frequently conducted in a non-standardised way and as such are non-comparable. The surveys might state that the survey was between 2-4 hours with no relationship to the size of the site or the extent of coverage. The resultant list of species without quantification of the populations or calculations of the proportional biomass of fruit bodies is of interest only as a record of presence or absence of particular species albeit an enjoyable exercise. 
Fig. 1 - Biodiversity Quality Calculator programme output showing the accumulation of species as each plot is surveyed and the number of specimens of each species. The bottom left hand corner of the chart shows the calculated Biodiversity Quality indices.

\section{Rapley $5(B F)$
$16 / 10 / 01$}

Samples used $=20$

Species name

GPS easting / SU $\begin{array}{llllll}1 & 2 & 3 & 4 & 5 & 6\end{array}$ (1) $\begin{array}{llllll}10 & 11 & 12 & 13 & 0 & 0\end{array}$ 14. $\quad 15 \quad 16 \quad 17 \quad 18$ $19 \quad 20$

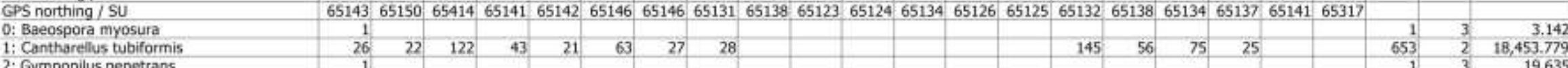

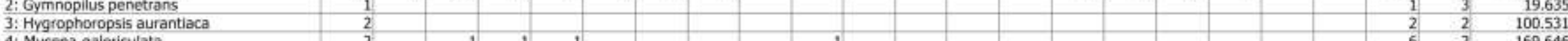

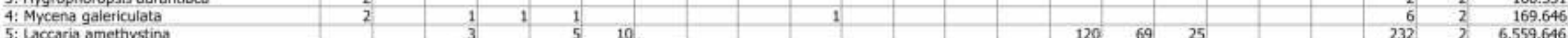

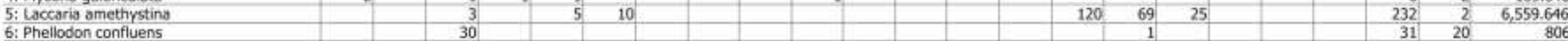

8: Russula emetica var silvestris

9: Russula achroleuca

10: Amanita vaginata

12: Hydnellum spongiosipes

13: Trectris fulvissimus

15: Lactarius camphoratus

16: Lactarius tabidus

17: Auriscalpium vulgare

19: Mycena inclinata

20: Psathyrella artemisio

22: Lactarius cimicarius

23: Mycena galogus

24: Mycena epipterygioides

25: Scleroderma citrinum

26: Mycena capillaris

27: Laccarla laccata

28: Cantharellus cibarius

29: Cortinarius flexipes var, flexipes

30: Hydnum repandum

31: Russula fragilis

33: Amanita fulva

34: Lyophyllum leucophaeatum

35: Tricholoma orirubens

36: Phellodon niger

37: Hydnellum concresceens

38: Russula fellea

summary

Species Richness $=39$

Shannon-Wiener Index $=1.6456(1.8001)$

Simpson Index $=2.8081(3.5415)$

Berger-Parker Dominance Index $=0.5557(0.4713)$

Density $=1.175$ per sq, m.

Species Conservation Value index $=4.2564+/ \cdot 3.2716$

Biomass Index $=39154.7213$

Chaol (pop.) Richness $=63.5+/-13,6416$

Chao2 (pres./abs.) Richness $=69.25+/ 13.5383$ 
Feest (2006) published a protocol for a standardised survey methodology so that sites might be compared or single sites might be followed for trends over time. This methodology allowed the measurement of a number of indices such that the balance/relationship between these indices will describe the biodiversity quality of the macrofungi of the site. Having the biodiversity quality of the site expressed as numerical indices also allows the statistical comparison of sites for difference temporally or spatially.

The relationship between species of fungi as denoted by the term mycosociology has been developing and in particular the group of species found on nutrient poor well grazed grassland ( the CHEG group of species: Clavaria, Hygrocybe, Entoloma and Geoglossidae) have been identified as of conservation importance (Rotheroe 1997). The question then becomes can a group of macrofungal species indicate the presence of other, especially rare, species? In the CHEG group this is clearly the case. Can a rare group be indicated to be present by the occurrence of other species? We have applied this argument to the case of stipitate hydnoid species that are the subject of conservation action in the UK due to their perceived rarity.

Our research hypothesis is therefore:

$\mathrm{H}_{1}$ Stipitate hydnoid species can be indicated as present by the observation of other indicator species.

In this hypothesis stipitate hydnoids are those we found within the genera Hydnum, Hydnellum, Phellodon and Sarcodon. Indicator species are species whose presence indicates either the presence or absence of Stipitate hydnoids.

\section{Materials and Methods}

We utilised a structured sampling process that allowed separate comparable surveys of macrofungi (Feest 2006). This survey methodology examined the fruit body content of $20 \times 4 \mathrm{~m}$ radius sample plots per site. The position of the sample plots was determined by adopting a linear transect through each site such that most parts of the site were visited but not particularly selected thus giving an unbiased picture of the whole site. The total area of the site examined was $20 \times$ $50 \mathrm{~m}^{2}\left(4 \mathrm{~m}\right.$ radius circle $\left.=50 \mathrm{~m}^{2}\right)=1000 \mathrm{~m}^{2}$ or $1 / 10^{\text {th }}$ hectare. The identity of each species occurring in a plot was confirmed in the field or microscopically (especially for critical species) and the number of fruit bodies of each species also recorded.

The sample sites were five woodland sites in the south of England collectively part of the Bracknell Forest. All sites selected were known to have had stipitate hydnoids present at some time in the past. The samples were taken in October at the time of maximal fruit body formation.

The data from the samples were entered into the biodiversity quality calculator (BQC (Fungib), ecosulis ltd.) and the resultant indices calculated (see Table 1). An example of the BQC output is presented in figure 1. The full dataset of 126 species in 119 plots (one plot did not contain any macrofungi) were entered onto the CAP 4 programme (PISCES Conservation ltd.) and a twinspan analysis conducted on presence absence data (since we were analysing associations) to show how occurrence was related and thus the mycosociology analogous to plant sociology determined.

\section{Results and Discussion}

Fig. 2 presents the Twinspan analysis graphical output and shows the relationship between species occurrence. One Stipitate hydnoid (Phellodon melalleucus) species occurs separately (in cluster 1) in this presentation and six others (Hydnellum concrescens, Phellodon niger, Sarcodon scabrum, Phellodon confluens, Hydnellum spongiosipes and Hydnum repandum) occur within a single cluster (cluster 2). Examination of the similarly sorted species shows that both of the clusters consist of almost entirely mycorrhizal species but this reflects that mycorrhizal species outnumber the saprophytic species in the overall sample. Cluster 2 identifies that one stipitate hydnoid species will strongly indicate the presence of other species and that the following species might be regarded as indicators that Stipitate Hydnoids are present: Cortinarius croceus, Lyophyllum leucophaetum,, Mycena polygramma, Tricholoma columbetta, Amanita vaginata, Armillaria mellea, Cantharellus 
Fig. 2 - Twinspan output showing clustering of stipitate hydnoids and their possible indicators.

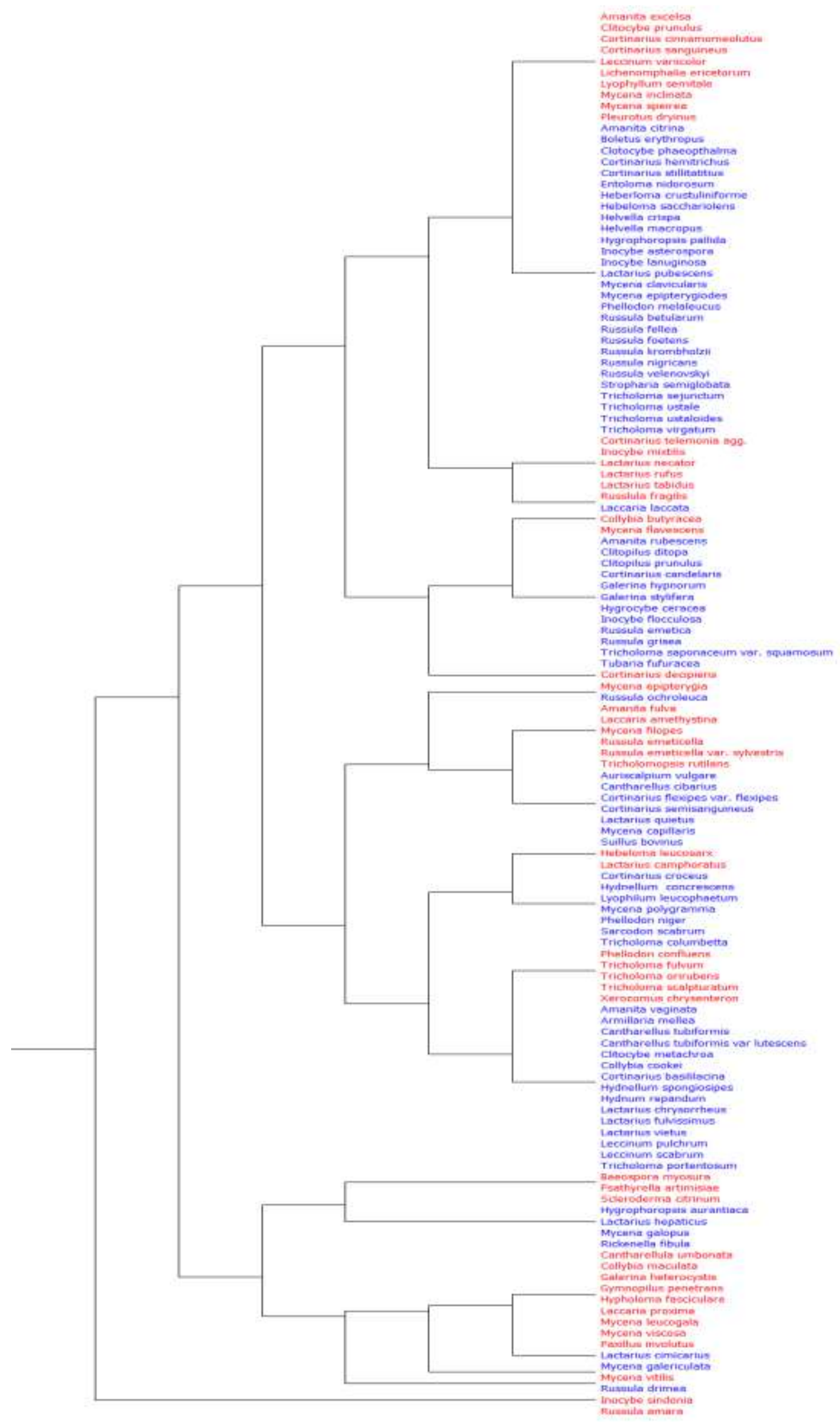


Table 1 Biodiversity quality indices of the five sites surveyed for presence of stipitate hydnoids.

\begin{tabular}{lrrrrr}
\hline Site & $\begin{array}{r}\text { Species } \\
\text { Richness }\end{array}$ & $\begin{array}{r}\text { Simpson } \\
\text { Index }\end{array}$ & $\begin{array}{r}\text { Fruit body } \\
\text { density }\end{array}$ & $\begin{array}{r}\text { Species value } \\
\text { Index }\end{array}$ & $\begin{array}{r}\text { Cap area } \\
\text { Index }\end{array}$ \\
\hline Buttersteep Hill & 38 & 7.604 & 1.041 & 4.184 & 35581 \\
Rapley 3 & 64 & 8.371 & 1.334 & 3.672 & 52697 \\
Rapley 4 & 43 & 7.321 & 0.814 & 3.791 & 29415 \\
Rapley 5 & 40 & 3.145 & 1.175 & 4.15 & 35392 \\
Rapley 9 & 47 & 6.668 & 0.838 & 3.574 & 41339 \\
\hline
\end{tabular}

tubaeformis (and var. lutescens), Clitocybe metachroa, Cortinarius basililacina, Lactarius chrysorrheus, Lactarius fulvisimus, Lactarius vietus, Leccinum pulchrum, Leccinum scabrum and Tricholoma portentosum.

Clearly this long list of species has difficulties in use as indicators since it contains some very common species (Armillaria mellea and Mycena polygramma are very common) and an analysis of the separation of the quadrat divisions output showed that at quadrat division level 5 (Table 2) with an eigenfactor of 0.40032 a positive association of the following was found Cantharellus tubaeformis, Hydnellum concrescens, Hydnellum spongiosipes, Phellodon confluens and Phellodon niger. Thus the list of indicators has been reduced to a single species: Cantharellus tubaeformis. This is a moderately common species probably best described as locally common and as such probably a good indicator of the presence of the stipitate hydnoids. Review of the species negatively indicated gives four species whose presence might indicate the absence of stipitate hydnoids: Laccaria laccata, Lactarius tabidus, Russula ochroleuca and Mycena galopus. These are all very common species and thus the combination of the presence of C. tubaeformis and the absence of L. laccata, L. tabidus, R. ochroleuca and M. galopus should enable a more targeted search for stipitate hydnoids.

Field evidence was that we clearly noticed $C$. tubaeformis was present when we found stipitate hydnoids and that the sites were frequently mossy earth banks and slopes with sharp drainage implying that dryness of the substrate was a requirement. This therefore complemented the above analysis.

Table 2 Twinspan output showing indicators of presence and absence of stipitate hydnoids.

QUADRAT DIVISION 5 Number of quadrates in cluster $=104$

eigenvalue $=0.400382$ number of iterations $=5$

Indicators and their sign

Cantharellus tubiformis [+];

Laccaria laccata [-];

Lactarius tabidus [-];

Russula ochroleuca [-];

Mycena galopus [-];

Variables preferring the negative group of quadrats

Laccaria laccata $1(31,1)$ Lactarius tabidus $1(26,2)$ Mycena galopus $1(25,2)$ Russlula fragilis 1 (15, 3) Scleroderma citrinum $1(20,0)$

Variables biased towards the positive group of quadrats

Cantharellus tubiformis $1(4,27)$ Hydnellum concrescens $1(6,7)$ Hydnellum spongiosipes $1(3,8)$ Phellodon confluens $1(2,8)$ Phellodon niger $1(6,10)$

Variables with no quadrat preference

Laccaria amethystina $1(28,14)$ Mycena galericulata $1(20,8)$ Mycena vitilis $1(10,8)$ Russula emeticella var. sylvestris $1(29,14)$ Russula ochroleuca $1(44,12)$ 


\section{Conclusions}

The use of a standardized sampling process has allowed analysis macrofungal fruit bodies to provide a list of five species indicating the presence or absence of stipitate hydnoids. In particular the presence of a suite of four common species eliminates a large number of sites from consideration and this accords with the rarity of records of stipitate hydnoids. Stipitate hydnoids are a clearly defined group of species and it remains to be seen whether other species groups could be subject to the same analysis.

\section{Acknowledgements}

This paper is dedicated to the memory of Justin Holger Smith who was a superb field mycologist and a generous and good person. It was a loss to mycology and society when he died at an early age with so much yet to do. This research was sponsored by Plant Life International.

\section{References}

Baldwin IT, Caldwell MM, Heldmaier G, Lange OL, Mooney HA, Schulze E-D, Sommer U 2002 Ecological Studies 157. Mycorrhizal Ecology, Springer-Verlag, Berlin.

Christensen M, Heilman-Clausen J, Adamcik S 2004 - Wood-inhabiting Fungi as Indicators of Nature Value in European Beech Forests in Monitoring and Indicators of Forest biodiversity in Europe - From Ideas to Operationality. EFI Proceedings No 51 ed. M Marcetti. European Forest Institute Joensuu, Finland. ISSN 145870-0610.

Dix NJ, Webster J 1995 - Fungal Ecology. Chapman \& Hall, London.

Feest A 2006 - Establishing baseline indices for the quality of the biodiversity of restored habitats using a standardized sampling process. Restoration Ecology 14, 112-122.

Ratowsky DA 2007 - Visualising Macrofungal Species Assemblage Compositions Using Canonical Discriminant Analysis. Australasian Mycologist 26(2-3), 75-85.

Remy W, Remy D, Haas H 1997 - Organisation, growth form and life strategies of early land plants from the lower Devonian. Botanische Jahrbuecher fuer Systematik Pflanzengeschichte und Pflanzengeographie. 119 (4), 509-562.

Rotheroe M 1997 - A comparative survey of Waxcap-Grassland Fungi of Ireland and Britain. JNCC report F76-01-71.

Smith SE, Read DJ 1997 - Mycorrhizal Symbiosis. Academic Press, San Diego, CA.

Walker JF, Miller OK Jr, Horton JL 2008 - Seasonal dynamics of ectomycorrhizal fungus. assemblages on oak seedlings in the South Eastern Appalachian mountains. Mycorrhiza 18, $123-32$. 